\title{
DOES FOREIGN AID PROMOTE TRADE? EVIDENCE FROM SOME SELECTED AFRICAN COUNTRIES
}

\author{
Paul Ojeaga, PhD Industrial Economics \\ Bergamo Italy Research Scholar Bentley University Boston 2011 to 2012 \\ Note This Paper is part of my PhD Dissertation deposited on AISBERG \\ repository Bergamo University Italy I also acknowledge the useful incites \\ from members of faculty of Economics and Mathematics. The views \\ expressed in the paper are solely those of the Author.
}

Doi: 10.19044/elp.v1no1a2 URL:http://dx.doi.org/10.19044/elp.v1no1a2

\begin{abstract}
Will aid given to specific sector promote growth? Will bilateral aid be more effective than multilateral aid in export promotion? This paper fills a gap in the literature by studying the implications of aid channeled specifically to trade and export oriented growth. Many African Countries look towards increase in trade driven growth as a means of improving living standards and boosting growth of their economies. Aid given to trade in desperately poor countries can be of tremendous advantage to such countries. We investigate some peculiar components of temporal self limiting aid (often referred to as development assistance) to sectors that can affect trade in developing countries. Aid to four sectors was found to have significant impact on trade although the presence of natural resources tends to reduce the effectiveness of aid in promoting trade. Institutions and government economic policies were also found to be weak in the African countries in our sample reducing aid overall effect on trade.
\end{abstract}

Keywords: Foreign Aid, Government Economic Policy, Institutional Quality, Trade

JEL: F13, F16, O24.

\subsection{Introduction}

The International Trade Centre (ITC) taskforce report 2010/13 states that global markets and export oriented growth are an effective way of alleviating poverty, improving livelihood and supporting entrepreneurship in a sustainable way. The Millennium Development Goals (MDGs) Gap taskforce report 2010 have also confirmed that "trade is a useful mechanism 
to realize the MDGs by the 2015 deadline" therefore trade is vital in driving growth. Studying aid-trade dynamics in this paper ${ }^{13}$ provides an insight into the possible effects that aid can have on trade with particular emphasis on Africa.

Exports (as a measure of trade) can have a strong effect on the living conditions of people in advanced countries where strong trading capabilities have already been attained and in developing countries that are emerging from economic and political disruptions who wish to establish strong trade ties (see ITC Trade Report 2010/2013 and DFID (Department for international Development) Strategy Report Working Paper on Economic Growth 2008/2013). Exports also has the capability to increase employment, improve earning power, raise government revenue to provide more services to its population, provide economic empowerment for the poor through commerce and deal with environmental and climatic problems, if the gains accruing from exports are used for common good (see International Trade Centre (ITC) Taskforce Report 2010/13 for details).

Africa's per capita GDP is also significantly low and that is why it remains the World poorest continent (see World Bank Statistics 2012). The African economy requires a strong industrial effort to drive it out of its current economic doldrums. The richest countries in Africa based on World Bank 2009 statistics are South Africa and Egypt, (measured by their purchasing power parity) with South Africa's GDP being around \$488.6 billion as of 2009, see Economic Watch "An African Economy Overview" (2010), however many African countries remain extremely poor. Foreign aid given to these poor countries can have strong effects on the economy of these countries (particularly in sub Saharan Africa), especially in circumstances where it consist of a significant percentage of their national budget or gross domestic product. If the reason behind giving foreign aid is purely altruistic, then foreign aid can have a positive impact on the recipient country's development, if well utilized.

The aims of this study is to identify what components of foreign aid (channeled to trade) is useful in promoting productivity and increasing trade in developing countries by dividing aid into sectors, and secondly to determine what the impact of government economic policy and institutional quality is on aid effectiveness in Africa? Previous papers have estimated reduced forms equations of trade aid dynamics they find that country specific economic and social variations and its proximity or distance to both local and foreign markets have a significant effect on trade (particularly exports)" see Morrissey, Osei and Lloyd (2004). In this paper it is assumed that aid is

\footnotetext{
13 I wish to express my thanks to Bergamo University Italy for funding the course of this research and for the guidance and feedback obtained in writing this paper.
} 
endogenous. The reason for this is that aid is likely to suffer from measurement problems since the data for aid might not capture all aid flows to developing countries for instance.

The econometric approach we use in the study is instrumental variable estimation, this allows us to control for endogenity. Aid to sectors was found to have little or no significant effect on trade using OLS, and it has a somewhat increased effect in sectors using two stage least squares. Lots of literatures have argued that aid is useful, while others have suggested that giving aid does not help developing countries achieve economic growth. Some papers e.g. that of Jempa (1991) ${ }^{14}$ examine vast literature on foreign aid and finds that foreign aid has the tendency to overshadow private savings, contribute to consumption spending and has no significant impact on a country's growth. Others like Boone $(1994,1996)$ find out that aid has no effect on investment.

Burnside and Dollar (1997) also find that aid is only beneficial to countries that have good policies in place. Other authors have found some similar inconclusive results regarding aid and growth (see Bourguignon and Sundberg, 2008; Douclouliagos and Paldam, 2007). There is also, conflicting evidence that aid may have a positive impact on growth (Gormanee et al, 2003; McPherson and Rakowski, 2001). In addition to endogeneity, Svensson (2000) finds that disaggregating aid into sectors is a more promising route in trying to identify the effects that aid can have on a developing country. Clemens et al (2004) uses sectoral aid and finds a positive short-run effect on economic growth and that institutional factors may impact the effectiveness of aid. See Renzio (2006) or Jensen (2008) for a review of aid literature. The rest of this paper is divided into five parts, the theoretical part, data description, some constraints to trade in Africa and index construction, empirical analysis and conclusion.

\subsection{Theory and Methodology}

The theoretical model we present suggest that some specifically channeled aid can influence exports, the simple export demand model as developed by Fontagne et al (2002) $)^{15}$, used by Morrissey et al (2004) and Cali and Velde (2009), shows the possible effect that aid can have on trade. If we assume a situation where each country produces one good, differentiated from the others as a result of its place of production (origin), with the supply of each good constant and consumers having identical and

\footnotetext{
14 Jempa, C. (1991) suggests that foreign aid in most cases does not contribute in a significant manner to a country's economic growth.

15 The model first developed by Fontague et al (2002) describes the role of country specific effect particularly infrastructure in determining trade cost. We extend this model to the private sector and show how aid will affect factors of production such as cost of capital, labor and cost of developing a suitable environment for trade.
} 
homothetic choices which is represented by a constant elasticity of substitution (CES) utility function. The overall utility function of individuals in a given country $\mathrm{k}$ can be defined as a sum of the utility function of individuals in country $i$. we represent this in equation 1 below as

$$
\text { (1.) } \quad U_{k}=\left(\sum_{i=1}^{N} \varphi_{i}{ }^{\frac{1}{\sigma}} C_{i k}{ }^{\frac{\sigma-1}{\sigma}}\right)^{\frac{\sigma}{\sigma-1}}
$$

Where $\sigma=$ elasticity of substitution of all goods and services, this can be defined as the share of goods and services from country i expended upon by individuals in country $\mathrm{k}$,

$\mathrm{C}_{i k}=$ the value of consumption of the goods produced in country $\mathrm{i}$ by individuals in country $\mathrm{k}, \varphi_{i}=$ share of goods produced by country $\mathrm{i}$, expended on by individuals in country $\mathrm{k}$,

where $\mathrm{k} \epsilon[1, \mathrm{~N}]$ this subject to the budget constraint that the value of goods and services consumed by individuals in country $\mathrm{k}$, needs to be equal to the total national income of country $\mathrm{k}$. The income of country $\mathrm{K}$ is given as shown in equation 2 below as

$$
\boldsymbol{y}_{\boldsymbol{k}}=\sum_{i=1}^{N} C_{i k} \boldsymbol{P}_{i k}
$$

Where $\mathrm{P}_{i k}=$ is the price in importer country $\mathrm{k}$ of goods produced in exporting country $i$

$\mathrm{P}_{i}$ is expressed as the supply price of the exporter $\mathrm{i}$

Then therefore $\mathrm{P}_{\mathrm{ik}}=\mathrm{P}_{\mathrm{i}} \tau_{\mathrm{ik}}$ where $\tau_{\mathrm{ik}} \geq 1$ which is the exporters price times the cost of transaction

This will capture all types of trade related transaction cost for example potential tariffs and import taxes, likely administrative cost of trade, , transportation to ports and other local and international market destinations etc see Cali and Velde (2009) for further discussion. After maximizing eqn.1 subject to the budget constraint in eqn. 2 the real consumption $C_{\mathrm{ik}}$ with respect to import of goods from country i by country $\mathrm{k}$ is given below as in equation 3 below

$$
\mathrm{C}_{\mathrm{ik}}=\frac{\varphi_{i} Y_{i}}{\tau_{i} P_{i}}\left(\frac{\varphi_{i} Y_{i}}{\tau_{i} P_{i}}\right)^{1-\sigma}
$$

The constant elasticity of substitution can be expressed as the likely trade cost in exporting to country $\mathrm{k}$ this can be defined as an index of how far in terms of distance, that country $\mathrm{k}$ is to country $\mathrm{i}$, given by the distance factor. The distance factor can be defined as how remote goods from country $\mathrm{i}$ are from the market of country $\mathrm{k}$. We express it in terms of remoteness in eqn. 4

$$
\mathbf{R}_{i}=\left(\sum_{i=1}^{N} \quad \varphi_{i} \boldsymbol{\tau}_{i}{ }^{1-\sigma} \quad \mathbf{P}_{i}^{1-\sigma}\right)^{\frac{1}{1-\sigma}}
$$

country's $\mathrm{k}$ income can be expressed as $\mathrm{y}_{k}=\mathrm{P}_{k} \mathrm{Q}_{k}$. which is the price multiplied by quantity consumed. The total export from country i to country 
$\mathrm{k}$ can be given as $\mathrm{X}_{i k}$ expressed below in terms of the exporting price and the total consumption in $\mathrm{k}$ of country $\mathrm{i}$ goods and services.

$$
\mathbf{X}_{i k}=\mathbf{C}_{i k} \mathbf{P}_{i}=\frac{\varphi_{i} \mathbf{Y}_{i}}{\tau_{i k}}\left(\frac{\mathbf{R}}{\mathbf{P}_{i}}\right)^{\sigma-1}
$$

The total exports from country i can also be expressed as

$$
\mathrm{X}_{i}=\frac{\varphi_{i}}{\mathbf{p}_{i}{ }^{\sigma-1}} \sum_{k=1}^{N} \frac{\mathbf{Y}_{i} \mathbf{R}_{k}{ }^{\sigma-1}}{\mathbf{\tau}_{i k}{ }^{\sigma}}
$$

This indicates that exports from country $i$ will depend significantly on individual country preferences for goods from i. This will depict how competitive, attractive and the degree to which goods from country $i$ are in demand in the international market. Total demand from country i therefore, will be affected in a negative manner by the cost of carrying out trade transaction in $\mathrm{i}$, since this will affect its final selling price. This will therefore be displayed by its constant elasticity of substitution $\sigma$ (CES). If the $\sigma=1$ this will mean that the CES is high therefore increases in price of goods from country i will lead to a significant decrease in exports since buyers will have to look elsewhere for cheaper goods, therefore change in exports with respect to price will reduce which we can express as $\frac{\partial \mathrm{x}_{i}}{\partial \mathrm{p}_{i}}<0$.

Incorporating foreign aid into our exports model, it is likely that it could influence a whole lot of factors that could lead to increase in exports. Some factors that it could influence are the quality of goods produced by a country which could lead to product competitiveness in the international market this will likely increase the country's share of trade $\varphi_{i}$. Secondly it could reduce transaction cost in carrying out trade since aid is likely to improve infrastructure this will make the final price of country i products to be cheaper. Finally it might also reduce administrative and legal cost since aid might strengthen both financial and civil institutions so as to increase access to capital and reduce the bureaucracy of obtaining business permits and processing exports at ports. We define all these as transaction cost $\tau_{i k}$ and express it below in equation 7 as

$$
\boldsymbol{\tau}_{i k}=\left(1+\mathbf{t}_{i k}\right) \mathbf{b}_{i} \mathbf{b}_{k} \mathbf{f}\left(\mathbf{I}_{i} \mathbf{I}_{k}\right) \mathbf{d}_{i k}
$$

Where $\tau_{i k}$ is the transaction cost of carrying out trade in $i$ relative to exporting to $\mathrm{k}$. We express $\mathrm{b}_{i}$ and $\mathrm{b}_{k}$ as the cost of processing exports in country $\mathrm{i}$ and $\mathrm{k}$ respectively. We assume that transaction cost is a linear function of distance between $i$ and $k$ therefore country specific infrastructure should exert a positive effect on transaction cost depending on its state. The factor $\mathrm{d}_{i k}$ is the trade distance between $\mathrm{i}$ and $\mathrm{k}$ and therefore a barrier that should be overcome for trade to take place this could also affect price significantly, $\mathrm{I}_{i}$ and $\mathrm{I}_{k}$ are the quality of infrastructure in country $\mathrm{i}$ and $\mathrm{k}$. This shows that aid given towards improving trade capacity is likely to facilitate trade in a positive manner by reducing transaction cost of trade in 
general. With this we establish that there might indeed exist, a relationship between trade and aid. This relationship can be expressed as the inverse function between trade transaction cost and infrastructure. We can express trade transaction cost to reflect this by writing it as shown in equation 8 . Where $\mathrm{I}_{d}$ is each country's domestic infrastructure and $\mathrm{A}_{4 I N F R}$ is aid channeled towards infrastructure.

$$
\boldsymbol{\tau}_{i k}=\frac{\left(1+\mathrm{t}_{i k}\right) \mathbf{b}_{i}\left(\mathrm{~A}_{4 T}\right) \mathbf{b}_{k} \mathbf{d}_{i k}}{\left(\mathrm{~A}_{4 I N F R}+\mathrm{I}_{D}\right)_{i}+\mathrm{I}_{k}}
$$

Putting equation 8 into 6 the export becomes

$$
\mathbf{X}_{i}=\frac{\left(\varphi_{i}\left(\mathbf{A 4}_{P C}\right)\right)\left(\mathbf{A}_{\text {IINFR }}+\mathbf{I}_{D}\right)_{i}{ }^{\sigma}}{\mathbf{P}_{i}{ }^{\sigma-1}\left(\mathbf{b}_{i}\left(\mathbf{A 4}_{T}\right)\right)^{\sigma}} \sum_{j=1}^{N} \frac{\mathbf{Y}_{i} \mathbf{R}_{k}{ }^{\sigma-1}}{\mathbf{E}_{i k}{ }^{\sigma}}
$$

Where $\mathrm{E}_{i k}$ represents the total cost of trade (in exports) by country $\mathrm{i}$ with all other countries. It is assumed therefore that different types of aid depending on the sector it is allocated to will likely have a positive effect on exports. Therefore we express a change in exports with respect to trade as shown in equation 10 below by including different constraints to trade.

$$
\frac{\partial \mathbf{X}_{i}}{\partial\left(\mathbf{A}_{4 T}\right)_{i}}=\frac{\partial \mathbf{X}_{i}}{\partial \mathbf{b}_{k}} \frac{\partial \mathbf{b}_{i}}{\partial\left(\mathbf{A}_{4 T}\right)_{i}}>\mathbf{0}
$$

A change in exports with respect to aid will depend on how aid given to boost trade will reduce cost of production within a given country (see Cali and Velde (2009) for further discussion on how aid can influence export oriented growth).

Relating this to the private sector, the approach of our model will depict how aid will affect trade within a country, which will be a straightforward profit-maximization problem where trade within a country leads to a situation where firms in the private sector are attempting to maximize their profits $\left(\pi_{i}\right)$. We can express profits $\left(\pi_{i}\right)$ as the difference between total revenue and total cost $\pi_{i}=T R_{i}-T C_{i}$. In constructing the total revenue function we will for simplicity assume that firms' quantity choice does not impact the output price. This will be particularly true for firms in the export sector as they will be selling at the world price. The total revenue function for firms operating in sector i can thus be written as the price of output from sector $i\left(P_{i}\right)$ multiplied by the output level $\left(X_{i}\right), T R_{i}=P_{i} X_{i}$. So, the marginal revenue is equal to the price $M R_{i}=P_{i}$. In sectors of an economy firm costs are a function of several factors. These include the cost of labor $(w)$, the cost of capital $(v)$, transportation costs $(t)$, and rent seeking $(r)$. The cost of labor is the wage rate per unit of output produced. The cost of capital can be viewed as the typical rental price of capital but also more broadly as to include additional factors impacting the cost of obtaining capital such as access to credit. Transportation costs are a function of both the distance to market and more importantly the level of infrastructure. For example, in many developing countries the distance in kilometers to market 
is considerably less important than the state of the roads that lead there. Rent seeking represents the cost of dealing with corrupt government officials imposed on firms. So, the firms total cost function can be written as $T C_{i}=$ $f_{i}(w, v, t, r) X_{i}$. The marginal cost (MC) can be expressed as $f_{i}(w, v, t, r)$. As firms increase output we can assume that eventually scarcities will occur and the marginal cost of production will rise. This can occur because of the rising cost of labor per unit of output produced and/or because of capital costs per unit is rising. Eventually, there reaches a point at which equilibrium occurs in firms. This profit maximization point $\left(X_{i}^{*}\right)$ will represent the point at which $M R_{i}=M C_{i}$, also expressed as $P_{i}=$ $f_{i}(w, v, t, r)$.

One of the goals of foreign aid $\left(a_{i}\right)$ is to improve conditions for private sector businesses in developing countries. There are many ways in which this can occur. Foreign aid can increase education and training of workers, which would lower the firms labor cost per unit produced. So, the wage cost per unit produced can be expressed as a negative function of foreign aid, $w_{i}\left(a_{i}\right)$. Aid may also be used to subsidize equipment/technology purchases for firms or come in the form of credit extensions which may be used for capital purchases. Therefore, we can write the cost of capital as a negative function of foreign aid, $v_{i}\left(a_{i}\right)$. It is common for both multilateral and bilateral aid to be used for infrastructure projects (roads, harbors, airports, etc). These would lower the transportation costs for firms resulting in the following function where transportation costs are a negative function of foreign aid, $t_{i}\left(a_{i}\right)$. The flow of foreign aid into a sector may have a negative side effect; however, by increasing the rent seeking behavior of government officials since more funds flowing into a sector may result in corrupt officials seeking higher payout from firms. Therefore, the costs imposed by rent seeking officials is modeled as a positive function of aid, $r_{i}\left(a_{i}\right)$. With foreign aid included in the model we can rewrite the equilibrium condition as $P_{i}=f_{i}\left[w_{i}\left(a_{i}\right), v_{i}\left(a_{i}\right), t_{i}\left(a_{i}\right) r_{i}\left(a_{i}\right)\right]$.

We can now examine the impact on the equilibrium condition from a change in foreign aid. We will assume that foreign aid does not impact output prices, especially for the export driven sector. Therefore, the differentiation of this condition with respect to foreign aid is only a differentiation of the marginal cost function. This can be expressed as

$$
\frac{\partial f_{i}}{\partial a_{i}}=\frac{\partial f_{i}}{\partial w_{i}} \frac{\partial w_{i}}{\partial a_{i}}+\frac{\partial f_{i}}{\partial v_{i}} \frac{\partial v_{i}}{\partial a_{i}}+\frac{\partial f_{i}}{\partial t_{i}} \frac{\partial t_{i}}{\partial a_{i}}+\frac{\partial f_{i}}{\partial r_{i}} \frac{\partial r_{i}}{\partial a_{i}}
$$

first expression on the right hand side $\left(\frac{\partial \mathrm{f}_{\mathrm{i}}}{\partial \mathrm{w}_{\mathrm{i}}} \frac{\partial \mathrm{w}_{\mathrm{i}}}{\partial \mathrm{a}_{\mathrm{i}}} \leq 0\right)$ represents foreign aid potentially lowering the cost of labor. They potentially lower cost of capital from aid is represented as $\frac{\partial f_{i}}{\partial v_{i}} \frac{\partial v_{i}}{\partial a_{i}} \leq 0$. The potential reduction in transport 
costs is shown as $\frac{\partial f_{i}}{\partial t_{i}} \frac{\partial t_{i}}{\partial a_{i}} \leq 0$. The possible rise in rent seeking costs is the last term on the right hand side which is $\frac{\partial \mathrm{f}_{\mathrm{i}}}{\partial \mathrm{r}_{\mathrm{i}}} \frac{\partial \mathrm{r}_{\mathrm{i}}}{\partial \mathrm{a}_{\mathrm{i}}} \geq 0$. Therefore, the overall impact of foreign aid is combining three potential cost reduction factors ( $w, v$, and $t$ ) with one potential cost increase (r). Whether or not the overall sign of $\frac{\partial f_{i}}{\partial a_{i}}$ is greater or less than zero will depend to a large extent on the quality of a country's institutions and on how the foreign aid is directed. If aid is directed towards more productive uses that lower firm' labor, capital and/or transport costs then this will help turn the prediction towards lower marginal costs. If marginal costs of production fall for firms as a result of foreign aid then output in the sector will increase. In other words, if $\frac{\partial \mathrm{f}_{\mathrm{i}}}{\partial \mathrm{a}_{\mathrm{i}}}<0$ then $\frac{\partial \mathrm{x}_{\mathrm{i}}}{\partial \mathrm{a}_{\mathrm{i}}}>0$. We do not use the gravity trade model because aid is typically between the rich and least developed nations however we use a partial log equation to depict the effect that aid can have on trade in developing countries. Therefore our model asserts that exports will depend on a set of exogenous variables $X_{i, t}$ and aid. Our set of exogenous variables consists of a set of variables that affect trade. The model we present is the trade model below in equation 12 . We extend the model to sectors and relate the effect of aid to sectors to total trade in a country to determine the effect that aid to each sector has on trade.

(12.) $\operatorname{Exports}_{i, t}=\beta_{0}+\beta_{1} X_{i, t}+\beta_{2} A_{i d}+\varepsilon_{i, t}$

We expect our above model, to yield the following hypotheses which will be tested in this paper for the export sector

Hypothesis \#1.) Aid focused directly on export promotion (extensions of trade credit, etc) will have a positive impact on exports.

Hypothesis \#2.) The positive impact of aid on exports will be reduced if the country has lower institutional quality (more corruption).

Hypothesis \#3.) Aid focused on infrastructure investments will increase exports.

Hypothesis \#4.) Due to conditionality, it is expected that multilateral aid will suffer from less rent seeking and will be directed more towards lowering firms' costs as opposed to bilateral aid. Therefore, the positive impact of aid on exports should be higher for multilateral aid rather than bilateral aid.

Hypothesis \#5.) Aid directed towards the agricultural and educational sector may or may not increase exports depending on whether the aid is promoting production for export or for domestic consumption. 


\subsection{Data and Sources}

The descriptive statistics of all data used, is presented below (see Table 1). We use panel data in our study. We obtain data for five African countries, four in sub Saharan Africa and one in North Africa (i.e. Kenya, Botswana, Ghana, Cameroon and Egypt) for a period of 39 years 1970 to 2008 although some data are missing.

\section{Dependent Variable}

Our dependent variable is exports, we use exports as our measure of trade, it is the total amount of goods and services exported overseas from a given country in constant US dollars, it however does not capture domestic trade which is a major limitation. Data for exports is obtained from World Bank database. Logarithm of exports is taken because the data on exports is too noisy therefore this helps to resolve scaling issues. Exports overseas depicts the exporting country's capacity to exports and its share of oversea trade which is often its foreign exchange earning capacity, therefore export is a vital measure of a country's international trade.

\section{Description of explanatory variables}

Data for aid, gross domestic product (GDP), Population, exchange rate, trade openness, government spending and inflation was also obtained from World Bank database. Two different measure of aid is used in this paper. One is effective aid (pure aid) which consist of grants and grants component of loans, initially constructed by Chang, Fernandez- Arias, and Serven (1999) and the other is official aid which we described as distorted and conditional in nature (distorted because donors often require recipient to use a sizable amount to import goods from donor countries) it also consists of grants and loans whose grants component is at least $25 \%$ according to World Bank data. This allows us to determine the difference in their respective impact on trade. Bilateral and multilateral aid is added up to obtain what we call total effective aid and total official aid respectively. Effective aid data was available only for a period of 1975 to 1985 and official aid data for the period of 1970 to 2008. We intend to compare the difference of the impact of effective aid from that of official aid on trade and note the difference between aid without conditionality (effective aid) and aid with conditionality (official aid) on trade since donor often require recipient to purchase goods from donor countries as a condition for giving official aid, this could make official aid to be too stringent thereby limiting its impact on trade. 
Table-1 Descriptive Statistics

\begin{tabular}{|c|c|c|c|c|c|}
\hline Variable & Observations & Mean & Std. Dev & Min & Max \\
\hline Log of exports & 195 & 3.25 & 0.48 & 1.21 & 4.32 \\
\hline Log of GDP/capita & 194 & 13.35 & 0.84 & 11.87 & 15.79 \\
\hline Natural Resources & 195 & 0.6 & 0.49 & 0 & 3 \\
\hline Exchange Rate & 195 & 1.15 & 1.92 & 0.0004 & 7.03 \\
\hline Landlocked Status & 195 & 1.8 & 0.4 & 1 & 2 \\
\hline Economic Policy & 190 & -1.25 & 1.09 & -1.80 & 5.22 \\
\hline Institutional Quality & 140 & -1.67 & 1.24 & -1.83 & 1.83 \\
\hline Crude price & 195 & 42.72 & 21.48 & 15.93 & 99.11 \\
\hline Life Expectancy & 195 & 55.04 & 5.11 & 44.63 & 68.41 \\
\hline Health Access & 140 & 73.33 & 22.62 & 5 & 99 \\
\hline Inflation & 190 & 15.05 & 17.4 & -3.21 & 122.88 \\
\hline Openness & 195 & 70.24 & 30.56 & 22.25 & 157.63 \\
\hline Torture & 140 & 0.59 & 0.61 & 0 & 2 \\
\hline Electoral Self Determination & 140 & 0.99 & 0.73 & 0 & 2 \\
\hline Freedom of movement & 140 & 1.01 & 0.82 & 0 & 2 \\
\hline Political Imprisonment & 140 & 0.87 & 0.83 & 0 & 2 \\
\hline Effective Bilateral Aid & 105 & 2.98 & 2.43 & 0.42 & 15 \\
\hline Effective Multilateral Aid & 105 & 1.41 & 1.37 & 0.11 & 6.4 \\
\hline Total Effective Aid & 105 & 4.39 & 2.98 & 0.77 & 16 \\
\hline Official Multilateral Aid & 195 & 1.62 & 1.64 & 0.03 & 8.28 \\
\hline Total Official Aid & 195 & 5.75 & 3.91 & 0.17 & 18.24 \\
\hline Log of Official aid to Education & 144 & -6.34 & 1.74 & -14.81 & -2.99 \\
\hline Log of Official aid to Agriculture & 145 & -6.1 & 1.77 & -10.68 & -3.46 \\
\hline Log of Official Aid to Infrastructure & 145 & -4.76 & 1.3 & -10.08 & -2.19 \\
\hline Log of Official Aid to Trade Policy & 130 & -6.96 & 1.89 & -13.28 & -3.23 \\
\hline Log of Official aid to industry & 144 & -6.84 & 1.85 & -13.41 & -3.04 \\
\hline School enrollment rate & 183 & 88.94 & 15.64 & 55.15 & 120 \\
\hline Life Expectancy in Years & 195 & 55.04 & 5.11 & 2 & 68.4 \\
\hline
\end{tabular}

Source: Authors compilation (from WDI dataset of the World Bank and other sources)

Effective aid to sectors was not available for individual sectors, comparing the difference in total aid allocation allows us to know the difference of the impact of official aid from effective aid on trade, so as draw conclusion of their impact on trade. Official aid to sectors alone was used to determine the impact of aid to sectors on trade this will probably affect our results since we lack data on effective aid to sectors. Data on official aid to sectors was obtained from The College of William and Mary Williamsburg 
Virginia aid data base www.aiddata.org, for the period of 1980 to 2008 (29 years) for five the sectors that we wish to consider their effect on trade, although some years of data are missing. The sectors are trade and business support services, infrastructure, education agriculture and industry. Country specific income was represented as GDP per capita which is the average per capita income of individuals in a country, exchange rate is the average dollar local currency exchange rate by country this captures fluctuation in the global economy that are likely to affect trade since the dollar is the global currency used in international trade. Economic liberalization rate was captured using the number of phone lines, since businesses are likely to acquire more phone lines in a liberalized economy than in a highly regulated one. We use indices to capture the effect of economic policy and institutional quality on trade in the presence of aid. This method of construction of the indices is shown in next section. Economic policy is the fluctuations in government regulatory decisions reflected in its monetary and trade policies. We capture this using inflation and trade openness variables and develop a single index for this using principal component analysis (PCA). Investors are likely to consider how sound and consistent government economic policy have been overtime in the cause o their future investment in the private sector of an economy. While institutional quality is reflective of government attitude and behavior towards governance. We capture these using political variables. Institutions will also capture a whole host of factors such as transaction cost involved in running businesses, the cost and time in acquiring business permits and the quality of infrastructure which will affect the cost of transportation to both local and foreign markets, since access roads linking rural agricultural areas to ports will depend on governments ability to create enabling environment for trade. We obtain data on institutions from Brigham University political data, we create an index also for institutions (see next section for index construction). Foreign direct investment is the inflow of foreign investment to the private business sector in a country in constant US dollars, school enrollment was used to capture the level of skill available in the labor market, this was the total school enrollment of boys and girls between the ages of 0 to 15 years of age, therefore we expect that this will affect the overall quality of manpower in countries which could have an effect on output productivity, all variables are for a period of 1970 to 2008 except otherwise stated.

\subsection{Some Constraints to Trade in Africa: Constructing economic and institutional indices}

Business surveys such as World business environment (WBE) report and World development reports (WBR) of the World Bank of 1999/2000 and 1996/1997 respectively have listed some constraints to foreign direct 
investment and trade in Africa (See Table 2). They used a sample of 413 and 540 firms respectively in Africa in the two surveys, and respondents were asked to determine on a four point scale $(1=$ no constraint and $4=$ severe constraint) for the first survey and six point scale $(1=$ no constraint and $6=$ severe constraint) for the second, to depict

Table-2 Constraints on Trade in Africa

\begin{tabular}{cccc}
\hline $\begin{array}{c}\text { WBE }(1=\text { no constraint } \\
\text { 4= severe constraint })\end{array}$ & \multicolumn{3}{c}{$\begin{array}{c}\text { WBR }(1=\text { no constraint } \\
\text { 6= severe constraint })\end{array}$} \\
\hline Corruption & 2.80 & Taxes and Regulation & 4.50 \\
Weak Infrastructure & 2.75 & Corruption & 4.47 \\
Street Crime & 2.70 & Weak Infrastructure & 4.28 \\
Inflation & 2.67 & Crime & 4.25 \\
Financing & 2.64 & Inflation & 4.11 \\
Organized Crime & 2.57 & Lack of Access to Finance & 3.95 \\
Political Instability & 2.43 & Policy Uncertainty & 3.88 \\
Taxes and Regulation & 2.24 & Cost Uncertainty & 3.75 \\
Exchange Rate & 2.15 & Regulation of Foreign Trade & 3.64 \\
\hline
\end{tabular}

Source: World Bank Business Report (2000), also used by Asiedu (2002)

Note: The table above shows the different constraints on trade in Africa using results from two World Bank surveys

the extent to which some factors constrained business operation in African countries for each of the reports. As can be seen above in Table 2, institutional and economic factors rank highest on the list of constraints to business and trade in Africa. Corruption, weak infrastructure and crime are the greatest institutional impediments to trade while inflation and financing are strong economic impediments to trade. Therefore having a good measure for institutional quality and economic policy as they affect trade is vital in determining the dynamics that affect trade in Africa. In this paper we group most of these constraints into institutional and economic factors and reduce the number of variables by creating an index which captures their effect.

Developing a single variable from a list of variables that have been identified to be relevant to our topic under study (trade) makes the discussion of what the effect of institution or policy is on trade to be easier. Most variables used to capture institutional quality are often political indicators, they show the direction of a country's internal governing style and are often used to rate the reputation of its government and its inclination to good governance through its affinity for democratic values. Principal component analysis (PCA) allows us to create a single index for economic policy and institutional quality, this is a statistical technique used, to derive summary measures from a set of variables by capturing their variation. The difficulty most economists face when considering institutions is that they find numerous indicators for institutions and it becomes difficult to analyze 
institutions using every single one of them. The variables we use to capture institutional quality are country specific freedom of movement and electoral self determination rate. These variables depict a country's respect for rights to social assembly and right to self electoral determination. The reason for using these two variables is that it allows us to capture country specific freedom of association since this could affect trade if people are prohibited from doing business because of their opposition to government or unnecessary threats to life and property. While electoral self determination rate allows us to capture political stability and the presence of enabling environment that can promote trade.

Governments also find it difficult to control many economic indicators, however some of the economic policies that governments float are captured using indicators that governments try to control, and some examples of such policies are its monetary, trade and fiscal policies. To capture these three policies economist use indicators such as inflation, trade openness and government spending or budget surplus to measure the effect of these policies on growth. The difficulty arising from using such indicators is that if one wants to talk about economic policy as an entity it also becomes virtually impossible or quite cumbersome using more than one indicator to discuss the effect of government economic policy on the issue under focus. Due to this difficulty we use these three indicators (inflation, trade openness and government consumption spending) to develop a single index for economic policy. In this paper we show the index construction below. We create the index for institutional quality using the two variables stated above. They are freedom of movement (freedmove), which is the right to social association and electoral self determination rate (elecsd) which captures political stability as stated earlier. We obtain these variables from Brigham university data set for political indicators developed by international nongovernmental organizations.

Freedom of association was developed by assigning a score of 0 in cases where it did not exist, 1 in situations where it was interfered with and 2 in cases where it was present. Electoral self determination rate was measured by assigning a score of 0 in cases where it did not exist, 1 in a case where it existed but there were some limitations and 2 in a case where citizens have ability to exercise full political and voting rights. Principal component analysis uses a weighted average of the underlying variables above to develop an index for institutional quality using the matrix of eigenvectors transformation allowing us to obtain an uncorrelated index from a group of correlated variables. The result of our scatter matrix plot using the two variables used for generating institutional quality is presented below in fig 1 . Where the variables 1 and 2 are freedom of movement and electoral self determination rate respectively. The scatter matrix shown below show that 
electoral self determination and freedom of movement are identically distributed (see blue dots) and closely correlated. This might not be clear but a case where variables are not correlated will be explained when developing the economic policy index subsequently.

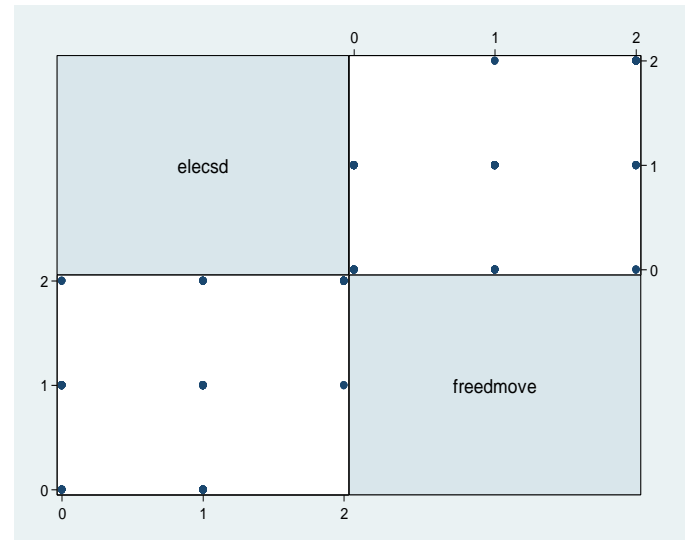

Fig.1 Above shows matrix plot the institutional variable

Table 3 Construction of institutional quality index using eigenvectors

\begin{tabular}{|c|c|c|}
\hline $\begin{array}{c}\text { Method of construction } \\
\text { Variables }\end{array}$ & $\begin{array}{c}(1) \\
\text { PCA } \\
\text { Component } 1\end{array}$ & $\begin{array}{c}(2) \\
\text { PCA } \\
\text { Component } \\
\end{array}$ \\
\hline toral self Determination Rate & 0.7071 & 0.7071 \\
\hline Freedom of movement & 07071 & -0.7071 \\
\hline
\end{tabular}

Note: The above values are generated using eigenvalue transformation. We used the PCA command "pca elecsd freedmove"to construct the institutional quality index in Table 3 above. The index captures the variation in the two variables allowing us to generate a single index by adding the individual principal component of the variables. This index obtained using PCA is uncorrelated with the dependent variable in our regression analysis.

The results of the eigenvectors values is obtained in Table- 1 above, (we show by hand below how this is constructed although "Stata" does it automatically) using the PCA command "pca elecsd freedmove". The index is obtained by adding the two principal components obtained from the eigenvalue transformation using the two variables alternately as shown below.

$P C 1=(0.7071 *$ elecsd $)+(0.7071 *$ freedmove $)$ and $P C 2=(0.7071 *$ elecsd $)-$ $(0.7071 *$ freedmove $)$ where freedmove $=$ freedom of movement and elecsd $=$ electoral self determination rate. Institutional quality index is given by Institutional quality $=\mathrm{PC} 1+\mathrm{PC} 2$ Where $\mathrm{PC} 1$ and $\mathrm{PC} 2$ are principal components 1 and 2 obtained from our variables. The score plot is shown below in figure 2 for the two components to depict the variation in our new 
index, it shows that there exist sufficient variations among our variables to capture the effect of institutions.

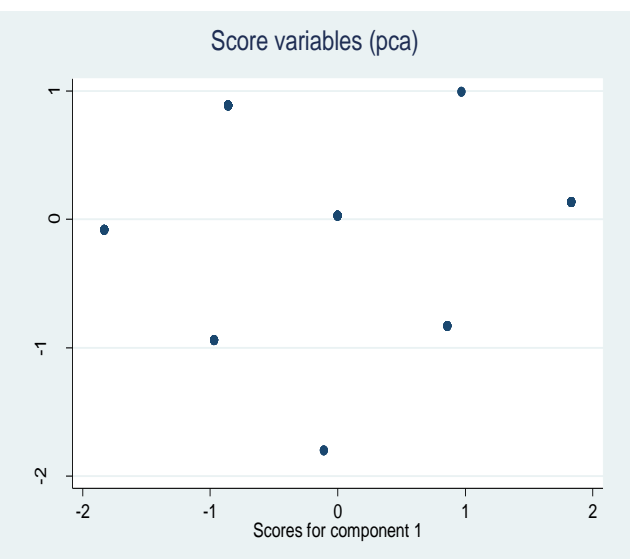

Fig.2 Above show the score plots for the institutional variable

An index for economic policy was also created using the three variables inflation, trade openness and government consumption spending which captures government monetary, trade and fiscal policies respectively. Inflation is the change in price of goods over time in US dollars, trade openness is the ratio of exports to imports by country and government consumption spending is government welfare spending in US dollars, which displays its fiscal discipline. The scatter matrix plot for the variables used in the construction of economic policy is shown below below in figure 3. The results of our scatter plot show that government consumption spending is not correlated with inflation but only openness (see comparison of the narrow blue scatter on the left with openness and inflation). We find that inflation and openness have a stronger correlation with each other. Using a set of uncorrelated variables could affect the quality of our index since it could either reduce the variation of the index or over exaggerate its variation making the index to have a strong negative or strong positive effect leading to poor conclusions as to the effect of the index in our study. Government consumption spending was dropped to avoid such problems and we used only inflation and trade openness in our index construction. Past literature e.g. Burnside and Dollar (2000) and Easterly (2003) also lend credence to our assertion since they state that countries can experience growth or trade increase with poor fiscal conditions (i.e. growing budget deficit) as most developed countries have for decades. 


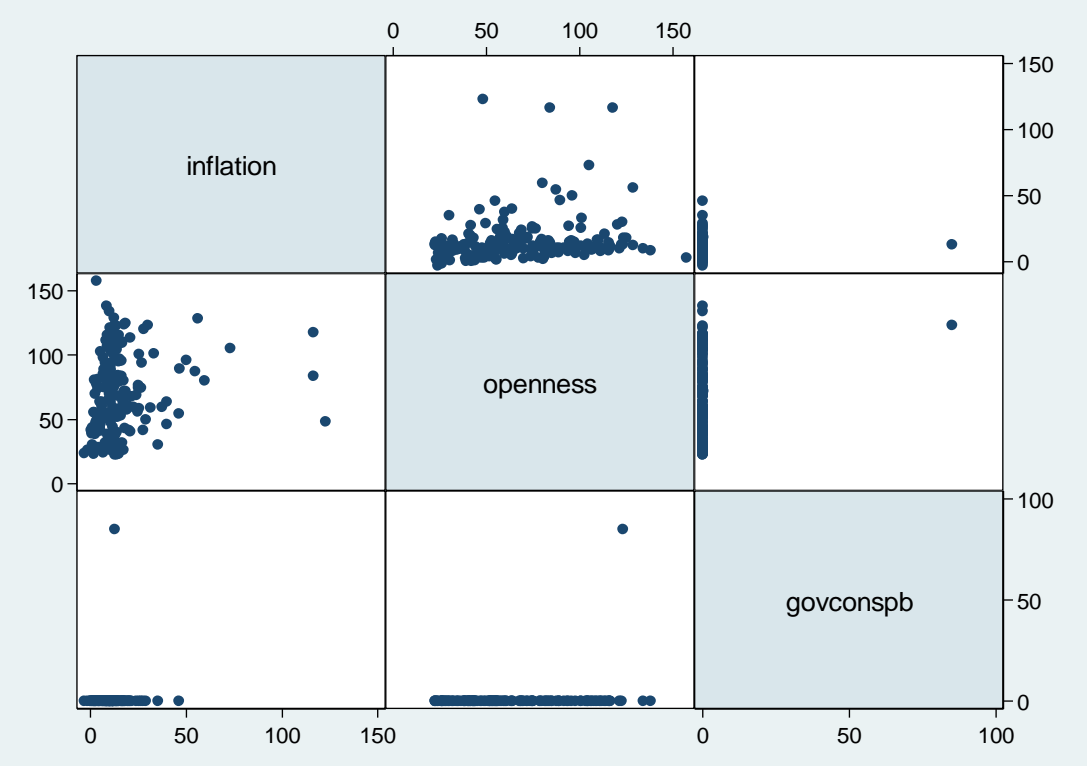

Fig3 Above show the matrix plot for the economic policy variable

The PCA command used to produce the eigenvectors in Table-4 is "pca openness inflation"

$\underline{\text { Table } 4 \text { Construction of Economic policy index using eigenvectors }}$

(1)

Method of construction

Variables

Variables
$\begin{gathered}\text { Openness } \\ \text { Inflation }\end{gathered}$

PCA

Component 1
(2)

PCA

Component 2

Note: The above values are generated using eigenvalue transformation. Using the PCA below we also show we construct the economic policy index from our matrix of eigenvectors as follows using the command "pca openness inflation" in the table above.

Economic policy index is generated from our principal component eigenvector table shown in Table- 4 above as $\mathrm{PC} 1=(0.7071$ *openness $)+$ $(0.7071 *$ inflation $)$ and $P C 2=(0.7071 *$ openness $)-(0.7071 *$ inflation $)$ Economic policy index is also obtained from summation of the principal components shown below as Economic policy index $=\mathrm{PC} 1+\mathrm{PC} 2$ where PC1 and PC2 are our principal component, 1 and 2 respectively. The results of the score plots also shows the correlation between openness and inflation in figure 4 whereas figure 5 shows all three variables, in figure 5 we observe that government consumption spending affects 


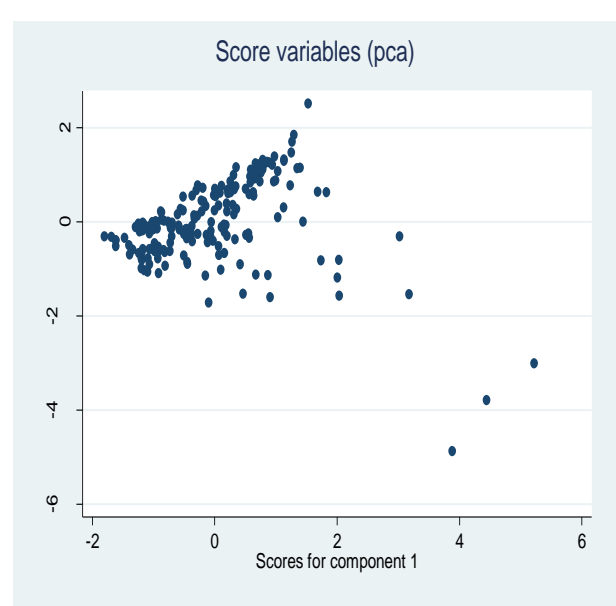

Fig4

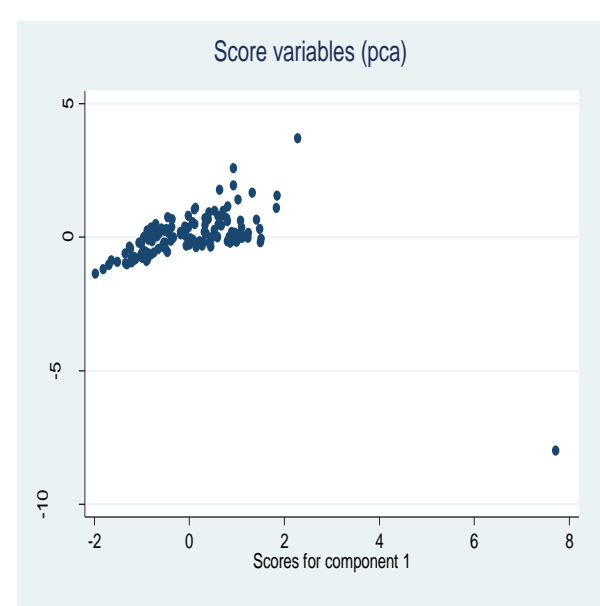

Fig5

Note: Fig 4 and 5 show the score plots for the policy variable

the spread of our score plots in such a manner as to skew our spread more in the positive direction (compare the spread on the vertical axis of both figures). This gives some more leverage as to why it was dropped. See Abeyasekera (2004) and Schlens (2009) for further discussion on how PCA produce consistent indices.

\subsection{Empirical Analysis}

\section{Does Aid Attract Trade?}

Our empirical model tries to answer, if aid promotes trade? The argument we present is that many middle income countries receive higher amounts of aid than low income countries (see USAID 2010 fast facts), this can be attributed to the fact that there is a higher volume of trade between middle income countries and developed countries who give aid. Based on this one might be tempted to say absolutely that it is trade alone that attracts aid. When one considers cases like that of Rwanda or Kenya that are particularly poor countries with little or no mineral resources and a low volume of trade but receive aid, we can state otherwise since there exists little or no incentive of giving aid to such countries. One can argue from sound judgment based on reasons for giving aid, that aid is initially altruistic to poor developing countries. Past studies e.g. Easterly (2003) suggest that giving aid to a country can establish a close connection between two countries leading donor country, to search for the presence of minerals and other country specific endowments in recipient country, on finding a sizeable deposit of resource this could lead to trade between both countries giving leverage to the argument that aid could be initially altruistic in nature, causing aid to attract trade. 


\section{Model specification}

Hausman specification test was run to choose between using fixed and random effects model for estimation. Results accept the null hypothesis that the fixed effects estimator is not biased (p-values are all considerably lower than .01). The use of instrumental variables approach is because of the endogeneity of the aid variables. A Hausman-Wu test rejected the null hypothesis that aid was exogenous, with a p-value of 0.00 . Therefore, using aid as an independent variable could lead to biased results. We then used fixed effect method of estimation to estimate our equations. We present the reduced forms of our three versions of aid and trade equations below (for effective, official and aid to sectors).

The EDA versions of these equations are

(13a) $E D A_{i, t}=\alpha_{0}+\alpha_{1} X_{i, t}+\alpha_{2} I_{i, t}+c_{i}+\mu_{i, t}$

(13b) Exports $_{i, t}=\beta_{0}+\beta_{1} X_{i, t}+\beta_{2} \widehat{E D A}_{i, t}+c_{i}+\mu_{i, t}$

The ODA versions of these equations are

(14a) $O D A_{i, t}=\alpha_{0}+\alpha_{1} X_{i, t}+\alpha_{2} I_{i, t}+c_{i}+\mu_{i, t}$

(14b) Exports $_{i, t}=\beta_{0}+\beta_{1} X_{i, t}+\beta_{2} \widehat{O D A}_{i, t}+c_{i}+\mu_{i, t}$

The sectoral versions of these equations are

(15a) $A I D_{i, t}^{j}=\alpha_{0}+\alpha_{1} X_{i, t}+\alpha_{2} I_{i, t}+c_{i}+\mu_{i, t}$

(15b) Exports $_{i, t}=\beta_{0}+\beta_{1} X_{i, t}+\beta_{2} A \widehat{I D_{t, t}^{J}}+c_{i}+\mu_{i, t}$

The trade (exports) equations are linear specifications, where $i$ is the index for the countries, $t$ the index for time and trade is the logarithm of per capita export resulting from trade with other countries, aid (be it EDA,ODA and aid to sectors) is expressed as the logarithm of aggregate aid allocated for purposes that can stimulate trade. Our vector of exogenous variables $X_{i, t}$ consists of a group of specific variables that affect trade they consist of government economic policy, average dollar-local currency exchange rates which capture global shocks that affect trade, institutional quality, school enrollment rate and GDP per capita. We excluded natural resources as a variable since we experience negative $\mathrm{R}$-squared with its presence but use it in interacting aid. We assume that aid is endogenous in the trade equations, since aid is likely to suffer from measurement problems. Therefore we employ an instrument $I_{i, t}$ for aid to capture the effect of aid in our aid equation. The dynamics that govern the different types of aid in promoting trade was found to be complex and different from one another. We find that with some types of aid, trade was found to depend on additional factors, since aid was to be used in promotion of trade, for instance with effective 
and official aid we found that such aid will likely be given to assist trade in the presence of reasonable foreign direct investment (FDI) and economic liberalization. With aid to sectors which was in fact official aid to sectors, aid will depend on some level of economic liberalization which allows for private ownership and some investment in the private sector but not necessarily foreign direct investment. Where $c_{i}$ represents time invariant unobserved effects on trade and $\mu_{\text {it }}$ represents time varying unobserved effects on trade. The fixed effect method will produce consistent estimate of the effect of aid on trade by allowing arbitrary correlation between unobserved time invariant effects $\left(c_{i}\right)$ and explanatory variables in the trade equations. The consistency of the FE estimators will depend on following assumption (a.) The time varying unobserved effects $\mu_{\mathrm{it}}$ are uncorrelated with the explanatory variables across all time periods. (b.) There is significant variation in aid flow over time and (c.) The assumption of strict exogeneity of explanatory variables is fulfilled. The assumption of strict exogeneity is going rules out feedback effects from aid to trade and country specific effects over time.

In some other instance we estimate variants of the trade (exports) equation using GLS including the variable "interact" the interaction between aid and policy, aid and institutional quality and aid and natural resources using interaction variables. The predicted value for the instrumented variable (sectoral aid) was then interacted with the institutional quality, economic policy or natural resources. The second equation (with exports as the dependent variable) then included the predicted aid variable, one of the interaction variables and the other explanatory variables used in all regressions.

The interaction versions of these equations are

(16a) $A I D_{i, t}^{j}=\alpha_{0}+\alpha_{1} X_{i, t}+\alpha_{2} I_{i, t}+v_{i}+\varepsilon_{i, t}$

(16b) Exports $_{i, t}=\beta_{0}+\beta_{1} X_{i, t}+\beta_{2} \widehat{A I D_{t, t}^{J}}+\beta_{3}$ interact $_{i, t}+v_{i}+\varepsilon_{i, t}$

In all government economic policy and income were lagged by one period. We have a total of two right hand side endogenous variables (logarithm of trade and aggregate aid) and at least 6 excluded exogenous variables (logarithm of income, government economic policy, and institutional quality, exchange rates, market access, foreign direct investment, economic liberalization rate and school enrollment rate) with three interaction variables (aid interacts with economic policy, institutional quality and natural resources). 


\section{Instrument}

Exclusion restriction assumptions are typically theoretical an instrument that is valid should therefore be correlated with aid in our model specification but not with trade (exports). One of the most important aspects of the instrumental variable approach is having a variable (or variables) in the aid equation which is not included in the trade (export) equation; these variables are referred to as the "instruments". We expect that our instruments should fulfill certain conditions in our case which will be particular for exports. First, instruments should have a significant impact on the variable they are predicting, in this case the aid variable. The second condition is that the instrument should not have an impact on the dependent variable, exports in the second equation. While often this is tested empirically, Wooldridge (2010) and others have pointed out that this also needs to be done on the theoretical level as testing the impact of the instrument on the dependent variable in the second equation (exports) with a full model could be biased as the instrumental correction has not been made for the endogenous variable (aid). We use one instrument "life expectancy" for aid (i.e. for bilateral, multilateral and aid to sectors for the three sets of equations), so our model is exactly identified, we expect aid to flow to areas with low life expectancy, making life expectancy to be positively correlated with aid. Our exclusion restriction will hold since it is reasonable to state that on the long run low life expectancy will attract foreign aid but will not promote exports allowing us to solve our first stage and second stage equations simultaneously.

The exclusion restriction we impose on our trade equation is that life expectancy is correlated with aid but not with trade, this will hold econometrically, if the coefficient for aid in our structural equation after imposing the restriction in our trade equation (where we use life expectancy as a proxy for aid) tends to that in our reduced form equation and secondly, if the correlation between the instrument $I_{i, t}$ and the error term $\varepsilon_{i, t}$ is identically equal to zero as shown below in equation 17 .

(17) $E\left|I_{i, t}, u_{i}\right|=0$ and $E\left|I_{i, t}, \epsilon_{i}\right|=0$

This then shows that the only way life expectancy is related with trade is only through aid therefore the instruments $I_{i, t}$ is not correlated with the disturbances $\left(u_{i}\right.$ and $\left.\epsilon_{i}\right)$ in our model specification and finally, if the exogenous component of the instrument, (the fitted value of aid) is uncorrelated with the error term we can therefore identify the variation of the dependent variable trade (exports) as the slope of the aid coefficient. This shows that there is sufficient variation (which is non zero) between aid and our instrument which we represent in the covariance (cov) equation 18 below.

(18) $\operatorname{Cov}\left(\operatorname{Aid}_{i, t}, I_{i, t}\right) \neq 0$ 
(where Aid can be EDA or ODA, this means that $\alpha_{2}$ in not zero). This implies that exports will vary according to changes in aid in flow to countries (see Kraay (2008) for further discussion on exclusion restriction). We argue that our instrument meet the criteria theoretically for our exclusion restriction to hold, since the behavior of the instrument life expectancy (see the first stage results and F-tests in Tables 5 to 7), support previous literature e.g. Heintz (2004) that argue that a good instrument should capture the variation in the dependent variable and be highly correlated with the endogenous variable therefore $\beta_{2}$ (our aid coefficient) will no longer biased in our model specification.

Table 5. First Stage: EDA Regressions

\begin{tabular}{|c|c|c|c|}
\hline Method of Estimation & $\begin{array}{c}\text { OLS } \\
\text { Bilateral EDA } \\
\end{array}$ & $\begin{array}{c}\text { OLS } \\
\text { Multilateral EDA }\end{array}$ & $\begin{array}{c}\text { OLS } \\
\text { Total EDA }\end{array}$ \\
\hline \multirow[t]{2}{*}{ Life Expectancy } & 0.36 & 0.35 & 0.71 \\
\hline & $(.12)^{* * *}$ & $(.11)^{* * *}$ & $(.20)^{* * *}$ \\
\hline \multirow[t]{2}{*}{ Policy Index } & -0.06 & -0.21 & -0.30 \\
\hline & $(.12)$ & $(.15)$ & $(.23)$ \\
\hline \multirow[t]{2}{*}{ Institution Index } & -0.0004 & -0.31 & -0.04 \\
\hline & $(0.35)$ & $(0.17)$ & $(0.34)$ \\
\hline \multirow[t]{2}{*}{ Exchange Rate (LCU per \$) } & 0.27 & 0.23 & 0.49 \\
\hline & $(.26)$ & $(.11)^{* *}$ & $(.30)$ \\
\hline FDI & $\begin{array}{l}-0.06 \\
(.89)\end{array}$ & $\begin{array}{c}-0.06 \\
(.06)\end{array}$ & $\begin{array}{l}-3.08 \\
(.10)^{* *}\end{array}$ \\
\hline School Enrollment Rate & $\begin{array}{l}0.01 \\
(.07)\end{array}$ & $\begin{array}{l}-0.12 \\
(.03)\end{array}$ & $\begin{array}{r}-0.11 \\
(.08)\end{array}$ \\
\hline Liberation Policy & $\begin{array}{r}-0.42 \\
(.88)\end{array}$ & $\begin{array}{c}0.97 \\
(.36)^{* *}\end{array}$ & $\begin{array}{c}1.38 \\
(1.03)\end{array}$ \\
\hline GDP per capita & $\begin{array}{l}-2.67 \\
(1.39)^{*}\end{array}$ & $\begin{array}{c}-0.47 \\
(.66)^{* * *}\end{array}$ & $\begin{array}{c}2.07 \\
(1.67)\end{array}$ \\
\hline F-Test & 8,23 & 10.13 & 12.90 \\
\hline $\mathrm{Chi}^{2}$ (p-value) & 0.00 & 0.00 & 0.00 \\
\hline \# of observations & 73 & 73 & 73 \\
\hline R-Squared & 22 & 52 & 36 \\
\hline
\end{tabular}

Notes: Coefficients listed with standard errors in parentheses. *,** and *** refers to significance at the $1 \%, 5 \%$ and $10 \%$ levels, respectively. First stage results in Appendix. 
Table 6. First Stage: ODA Regressions

\begin{tabular}{cccc}
\hline Method of Estimation & OLS & OLS & OLS \\
& Bilateral EDA & 0.16 & 0.44 \\
Life Expectancy & 0.28 & $(.04)^{* * *}$ & $(.08)^{* * *}$ \\
Policy Index & $(.05)^{* * *}$ & -0.35 & -0.56 \\
& -0.24 & $(.15)^{* *}$ & $(.26)^{* *}$ \\
Institution Index & $(.15)$ & -0.03 & 0.26 \\
& 0.24 & $(0.16)$ & $(0.32)$ \\
Exchange Rate (LCU per $\$)$ & $(0.20)$ & 0.22 & -0.18 \\
& -0.42 & $(.13)$ & $(.40)$ \\
FDI & $(.31)$ & 0.03 & 3.10 \\
& -0.08 & $(.04)$ & $(.09)$ \\
School Enrollment Rate & $(.06)$ & -0.06 & -0.04 \\
& 0.02 & $(.02)^{* * *}$ & $(.04)$ \\
Liberation Policy & $(.03)$ & -0.13 & -1.75 \\
& -0.63 & $(.07)^{*}$ & $(1.58)$ \\
GDP per capita & $(.12)^{* * *}$ & -0.56 & 4.47 \\
F-Test & -3.95 & $(.39)$ & $(1.02)^{* * *}$ \\
Chi ${ }^{2}$ (p-value) & $(.75)^{* * *}$ & 13.54 & 29.52 \\
\# of observations & 37.28 & 0.00 & 0.00 \\
R-Squared & 0.00 & 131 & 131 \\
Notes: Coefficient & 131 & 0.34 & 0.48 \\
\hline
\end{tabular}

Notes: Coefficients listed with standard errors in parentheses. *, ** and *** refers to significance at the $1 \%, 5 \%$ and $10 \%$ levels, respectively. First stage results in Appendix. 
Table 7. First Stage:Sectoral Aid Regressions

\begin{tabular}{ccccc} 
& $\begin{array}{c}\text { Aid to } \\
\text { Trade }\end{array}$ & $\begin{array}{c}\text { Aid to } \\
\text { Infrastructure }\end{array}$ & $\begin{array}{c}\text { Aid to } \\
\text { Agriculture }\end{array}$ & $\begin{array}{c}\text { Aid to } \\
\text { Education }\end{array}$ \\
\hline Life Expectancy & 0.23 & 0.16 & 0.13 & 0.18 \\
& $(.08)^{* * *}$ & $(.04)^{* * *}$ & $(.04)^{* * *}$ & $(.05)^{* * *}$ \\
Policy Index & 0.27 & -0.02 & -0.02 & -0.14 \\
& $(.24)$ & $(.15)$ & $(.17)$ & $(.32)$ \\
Institution Index & 0.21 & 0.04 & 0.37 & 0.39 \\
& $(.24)$ & $(.13)^{* * *}$ & $(.14)^{* * *}$ & $(.20)^{*}$ \\
Exchange Rate (LCU per $\$)$ & -0.05 & -0.01 & 0.30 & -0.23 \\
& $(.33)$ & $(.13)$ & $(.33)$ & $(.25)$ \\
School enrollment & -0.02 & 0.01 & -0.04 & 0.04 \\
& $(.02)$ & $(.01)^{* * *}$ & $(.02)$ & $(.02)^{*}$ \\
Liberalization policy & -0.11 & -0.09 & 0.12 & -0.17 \\
& $(.12)$ & $(.08)^{* *}$ & $(.08)$ & $(.09)^{* *}$ \\
GDP per capita & -0.78 & -1.25 & -0.03 & -2.40 \\
& $(.52)$ & $(.42)^{* * *}$ & $(.57)$ & $(.57)^{* * *}$ \\
F-Test & 7.95 & 18.72 & 10.25 & 14.24 \\
Chi ${ }^{2}$ (p-value) & 0.00 & 0.00 & 0.00 & 0.00 \\
\# of observation & 132 & 140 & 140 & 139 \\
R-Squared & 0.21 & 0.43 & 0.28 & 0.25 \\
\hline
\end{tabular}

Notes: Coefficients listed with standard errors in parentheses. *,** and *** refers to significance at the $1 \%, 5 \%$ and $10 \%$ levels, respectively. First stage results in Appendix.

\section{Results}

We use fixed effect regression as stated earlier, since the result of the Hausman test with p-value $0.000^{16}$ (we included this in our results only for aid to sectors results) suggest that fixed effect estimation is more appropriate for our model, see Baltagi (2005), Baltagi and Wu (2010) and Wooldridge (2010) for further discussion. We find that the factors that affect effective aid are quite different from those of official aid since effective aid is pure aid devoid of conditionality. Time effect "year" is included to control for

\footnotetext{
16 This did not hold in some cases with effective and official aid
} 
differences in exports from countries in years. This allows us to control, for production shocks and fluctuations in global demands for exports that is likely to affect volumes of exports. We present our result for effective aid and official aid below in Tables 8 to 11 . We compare the results of the OLS estimates with those of the 2SLS. As expected the results of the standard errors of our 2SLS estimates are larger than those of our OLS estimates for aid see standard errors in Table 8 and 9 for our regressions of trade (using $\log$ of exports) on effective aid and other factors that affect trade. In Table 8 the OLS estimate for bilateral and multilateral effective aid are 0.06 and 0.10 respectively (see coefficients in table 8 Column 1 and 2) it shows that bilateral aid contributed 6 percentage points towards trade (with p-value 0.037) while multilateral aid contributed 10 percentage points to trade but had a stronger effect (with p-value 0.023) on trade. But the estimate is quite different when we use 2SLS in Table 9 the result of the F-test for excluded instruments for the 2SLS shows that the instrument life expectancy is valid and highly correlated with aid (see first stage regression results for effective aid). The estimated aid effect on trade is now 0.15 and 0.16 (see Table 9 Column 1 and 2) using 2SLS showing that multilateral aid contributed about 1 percentage point more to trade (with p-value 0.03) compared to bilateral trade with only 15 percent (with p-value 0.07 ). This showed that controlling for endogeneity helps solve the problem of aid measurement, through the instrumental correction of aid since this could lead to bias in our results.

The results of the regression of trade on official aid are presented in tables 10 and 11. The result of the OLS regression with estimates for bilateral and multilateral official aid respectively of 0.06 and 0.05 in Table 10 Column 1 and 2, shows that bilateral aid contributed 6 percentage points to trade (with p-value of 0.000 ), while multilateral aid contributed 5 percentage points (with p-value of 0.052) to trade which is 1 percentage points less than bilateral aid contribution to trade. The results of our 2SLS estimates where we control for endogeneity are different from our OLS estimates. The result of the F-test for excluded instruments shows that our instrument life expectancy is valid and highly correlated with aid (see first stage official aid regression). The result in Table 11 Columns 1 and 2 shows that bilateral aid contributes 12 percentage points to trade (with p-value 0.000 ) while multilateral aid contributes 21 percentage points to trade with ( p-value of 0.000) which is 9 percentage points more than bilateral aid contribution $t$ trade. This result suggests once again that using 2SLS to address the issue of endogeneity is important, since aid is likely to suffer from measurement problems making the OLS results to be biased. Table 12 and 13 present the estimates of the regression of trade on aid to sectors and factors that affect trade in sectors. The result of our OLS estimates (see Table 12) show that aid to sectors had no effect on trade except for aid to 
infrastructure that contributed 10 percentage points to trade (with $\mathrm{p}$-value 0.000) while aid to trade policy and business support services, agriculture and education contributed 2,1 and 3 percentage points to trade respectively and had no significant effect on trade. The results of our 2SLS are different from that of the OLS estimates for aid to sectors. Aid had a significant effect in four sectors, With aid to trade and business support services, infrastructure, agriculture and education contributing 15, 22, 17 and 16 percentage points respectively to trade using 2SLS (see Table 13 Columns 1, 2,3 and 4 for aid estimates of $0.15,0.22,0.17$ and 0.16 respectively) therefore controlling for endogeneity using 2SLS was also relevant in this case. Aid to industry had no significant effect on trade so we left that out in our results. The result of our F- test show that our instrument is relevant and valid since it is highly correlated with aid (see first stage results using official aid to sectors). Finally GLS was used in estimating our trade equation with the interactive variables, the three interactive variables aid*economic policy, aid*institutions and aid*natural resources had reduced effect on trade showing that these variables reduce aid effectiveness (we show results in the Appendix-A to $\mathrm{C}$ in Tables 14 to 16). Based on the above results we answer the hypothesis that we posed earlier as follows

Hypothesis \#1.) Aid focused directly on export promotion (extensions of trade credit, etc) was found to be contributing to exporting in a significant manner. Therefore aid channeled to sectors that could improve output productivity is likely to be useful in promoting trade.

Hypothesis \#2.) Institutions were probably contributing negatively to aid effectiveness in promoting exports. The interactive variable aid*institutions had a reduce effect on exporting. It is likely that institutions are weak and not helping in effective utilization of aid to promote trade.

Hypothesis \#3.) Aid focused on infrastructure investments was found to be contributing to exports in a positive manner. It is likely that aid used in developing infrastructure will likely create enabling environment that can promote trade by way of cost reduction in the trade facilitation process.

Hypothesis \#4.) Multilateral aid was found to be contributing to exporting in a more significant manner than bilateral aid. It is likely that the altruistic nature and good policy requirement conditions associated with multilateral aid made it more effective in promoting trade than bilateral aid.

Hypothesis \#5.) Aid directed towards agriculture and education sector contributed to exporting significantly. It is likely that aid used in improving the level of education of the working population as well as modernizing methods used in cultivation was useful to improving trade. 
Table 8. Impact of EDA on Exports

\begin{tabular}{|c|c|c|c|}
\hline Method of Estimation & $\begin{array}{l}\text { OLS } \\
(1)\end{array}$ & $\begin{array}{l}\text { OLS } \\
(2)\end{array}$ & $\begin{array}{l}\text { OLS } \\
\text { (3) }\end{array}$ \\
\hline \multirow[t]{2}{*}{ Bilateral EDA } & 0.06 & - & - \\
\hline & $(.03)^{* *}$ & & \\
\hline \multirow[t]{3}{*}{ Multilateral EDA } & - & 0.10 & - \\
\hline & & $(.04)^{* *}$ & \\
\hline & & & 0.06 \\
\hline Total EDA & - & - & $(.02)^{* * *}$ \\
\hline Policy Index & $\begin{array}{l}0.08 \\
(.05)\end{array}$ & $\begin{array}{l}0.07 \\
(.05)\end{array}$ & $\begin{array}{l}0.07 \\
(.05)\end{array}$ \\
\hline Institution Index & $\begin{array}{c}0.28 \\
(.06)^{* * *}\end{array}$ & $\begin{array}{c}0.30 \\
(.06)^{* * *}\end{array}$ & $\begin{array}{c}0.28 \\
(.06)^{* * * *}\end{array}$ \\
\hline School enrollment & $\begin{array}{c}0.01 \\
(.004)^{* * *}\end{array}$ & $\begin{array}{c}0.02 \\
(.004)^{* * *}\end{array}$ & $\begin{array}{c}0.02 \\
(.004)^{* * *}\end{array}$ \\
\hline \multirow[t]{2}{*}{ Exchange rate (LCU per \$) } & 0.08 & 0.09 & 0.09 \\
\hline & $(.04)^{*}$ & $(.04)^{* *}$ & $(.04)^{* *}$ \\
\hline \multirow[t]{2}{*}{ Liberalization policy } & 0.09 & -0.29 & 0.18 \\
\hline & $(.10)$ & $(.12)^{* *}$ & $(.10)^{*}$ \\
\hline \multirow[t]{2}{*}{ FDI } & 0.06 & 0.06 & 0.06 \\
\hline & $(.02)^{* * *}$ & $(.02)^{* *}$ & $(.02)^{* *}$ \\
\hline \multirow[t]{2}{*}{ GDP per capita } & 0.15 & 0.19 & 0.22 \\
\hline & $(.10)$ & $(.10)^{*}$ & $(.10)^{* *}$ \\
\hline $\mathrm{Chi}^{2}$ (p-value) & 0.00 & 0.00 & 0.00 \\
\hline \# of observations & 73 & 73 & 73 \\
\hline R-Squared & 0.72 & 0.73 & 0.73 \\
\hline
\end{tabular}

Notes: Coefficients listed with standard errors in parentheses. *,** and *** refers to significance at the $1 \%, 5 \%$ and $10 \%$ levels, respectively. First stage results in Appendix. 
Table 9. Impact of EDA on Exports

\begin{tabular}{|c|c|c|c|}
\hline Method of Estimation & $\begin{array}{c}\text { 2SLS } \\
(1)\end{array}$ & $\begin{array}{c}\text { 2SLS } \\
\text { (2) }\end{array}$ & $\begin{array}{c}\text { 2SLS } \\
\text { (3) }\end{array}$ \\
\hline \multirow[t]{2}{*}{ Bilateral EDA } & 0.15 & - & - \\
\hline & $(.09)^{*}$ & & \\
\hline \multirow[t]{3}{*}{ Multilateral EDA } & - & 0.16 & - \\
\hline & & $(.07)^{* *}$ & \\
\hline & & & 0.08 \\
\hline Total EDA & - & - & $(.04)^{* * *}$ \\
\hline \multirow[t]{2}{*}{ Policy Index } & -0.11 & -0.09 & -0.10 \\
\hline & $(.06)^{* *}$ & $(.05)^{*}$ & $(.05)^{*}$ \\
\hline \multirow[t]{2}{*}{ Institution Index } & 0.14 & 0.15 & 0.15 \\
\hline & $(.06)^{* *}$ & $(.04)^{* * *}$ & $(.05)^{* * *}$ \\
\hline \multirow[t]{2}{*}{ School enrollment } & -0.001 & 0.02 & 0.01 \\
\hline & $(.01)$ & $(.01)^{* *}$ & $(.01)$ \\
\hline \multirow[t]{2}{*}{ Exchange rate (LCU per \$) } & 0.21 & 0.21 & 0.21 \\
\hline & $(.11)^{* *}$ & $(.08)^{* * *}$ & $(.09)^{* *}$ \\
\hline \multirow[t]{2}{*}{ Liberalization policy } & -0.13 & -0.04 & -0.09 \\
\hline & $(.17)$ & $(.10)^{* *}$ & $(.13)^{*}$ \\
\hline \multirow[t]{2}{*}{ FDI } & 0.01 & -0.01 & 0.001 \\
\hline & $(.02)^{* * *}$ & $(.01)^{* *}$ & $(.01)^{* *}$ \\
\hline \multirow[t]{2}{*}{ GDP per capita } & 0.12 & 0.61 & 0.38 \\
\hline & $(.45)$ & $(.18)^{* * *}$ & $(.27)$ \\
\hline $\mathrm{Chi}^{2}$ (p-value) & 0.00 & 0.00 & 0.00 \\
\hline \# of observations & 73 & 73 & 73 \\
\hline R-Squared & 0.28 & 0.51 & 0.64 \\
\hline
\end{tabular}

Notes: Coefficients listed with standard errors in parentheses. *,** and $* * *$ refers to significance at the 1\%,5\% and 10\% levels, respectively. First stage results in Appendix. 
Table 10. Impact of ODA on Exports

\begin{tabular}{|c|c|c|c|}
\hline Method of Estimation & $\begin{array}{c}\text { OLS } \\
\text { (1) }\end{array}$ & $\begin{array}{c}\text { OLS } \\
\text { (2) }\end{array}$ & $\begin{array}{c}\text { OLS } \\
\text { (3) }\end{array}$ \\
\hline Bilateral ODA & $\begin{array}{c}0.06 \\
(.02)^{* * *}\end{array}$ & - & - \\
\hline Multilateral ODA & - & $\begin{array}{l}0.05 \\
(.02)^{*}\end{array}$ & - \\
\hline Total ODA & - & - & $\begin{array}{c}0.04 \\
(.01)^{* * * *}\end{array}$ \\
\hline Policy Index & $\begin{array}{l}-0.10 \\
(.04)\end{array}$ & $\begin{array}{l}-0.11 \\
(.05)\end{array}$ & $\begin{array}{l}-0.10 \\
(.04)\end{array}$ \\
\hline Institution Index & $\begin{array}{c}0.23 \\
(.04)^{* * *}\end{array}$ & $\begin{array}{c}0.25 \\
(.04)^{* * *}\end{array}$ & $\begin{array}{c}0.23 \\
(.04)^{* * *}\end{array}$ \\
\hline School enrollment & $\begin{array}{c}0.01 \\
(.003)^{* * *}\end{array}$ & $\begin{array}{c}0.01 \\
(.003)^{* * *}\end{array}$ & $\begin{array}{c}0.01 \\
(.003)^{* * *}\end{array}$ \\
\hline Exchange rate (LCU per \$) & $\begin{array}{l}-0.01 \\
(.02)\end{array}$ & $\begin{array}{l}-0.01 \\
(.02)\end{array}$ & $\begin{array}{l}-0.01 \\
(.02)\end{array}$ \\
\hline Liberalization policy & $\begin{array}{l}0.02 \\
(.02)\end{array}$ & $\begin{array}{l}0.02 \\
(.02)\end{array}$ & $\begin{array}{l}0.02 \\
(.02)\end{array}$ \\
\hline FDI & $\begin{array}{c}0.03 \\
(.02)^{*}\end{array}$ & $\begin{array}{c}0.03 \\
(.02)^{* *}\end{array}$ & $\begin{array}{l}0.03 \\
(.02)^{*}\end{array}$ \\
\hline GDP per capita & $\begin{array}{c}0.17 \\
(.06)^{* * *}\end{array}$ & $\begin{array}{c}0.12 \\
(.06)^{* *}\end{array}$ & $\begin{array}{c}0.19 \\
(.06)^{* * *}\end{array}$ \\
\hline $\mathrm{Chi}^{2}$ (p-value) & 0.00 & 0.00 & 0.00 \\
\hline \# of observations & 131 & 131 & 131 \\
\hline R-Squared & 0.64 & 0.61 & 0.64 \\
\hline
\end{tabular}

Notes: Coefficients listed with standard errors in parentheses. *,** and *** refers to significance at the $1 \%, 5 \%$ and $10 \%$ levels, respectively. First stage results in Appendix. 
Table 11. Impact of ODA on Exports

\begin{tabular}{|c|c|c|c|}
\hline Method of Estimation & $\begin{array}{c}\text { 2SLS } \\
\text { (1) }\end{array}$ & $\begin{array}{c}\text { 2SLS } \\
(2)\end{array}$ & $\begin{array}{c}\text { 2SLS } \\
\text { (3) }\end{array}$ \\
\hline \multirow[t]{2}{*}{ Bilateral ODA } & 0.12 & - & - \\
\hline & $(.03)^{* * *}$ & & \\
\hline \multirow[t]{3}{*}{ Multilateral ODA } & - & 0.21 & - \\
\hline & & $(.06)^{* * *}$ & \\
\hline & & & 0.07 \\
\hline Total ODA & - & - & $(.02)^{* * *}$ \\
\hline \multirow[t]{2}{*}{ Policy Index } & -0.05 & -0.01 & -0.04 \\
\hline & $(.07)$ & $(.07)$ & $(.07)$ \\
\hline \multirow[t]{2}{*}{ Institution Index } & 0.14 & 0.16 & 0.15 \\
\hline & $(.05)^{* * *}$ & $(.05)^{* * *}$ & $(.05)^{* * *}$ \\
\hline \multirow[t]{2}{*}{ School enrollment } & -0.001 & 0.01 & 0.04 \\
\hline & $(.001)$ & $(.004)^{* * *}$ & $(.003)$ \\
\hline \multirow[t]{2}{*}{ Exchange rate (LCU per \$) } & -0.02 & -0.12 & -0.06 \\
\hline & $(.07)$ & $(.06)^{*}$ & $(.06)$ \\
\hline \multirow[t]{2}{*}{ Liberalization policy } & 0.05 & -0.0002 & 0.03 \\
\hline & $(.02)^{* *}$ & $(.01)$ & $(.01)^{*}$ \\
\hline FDI & $\begin{array}{l}0.02 \\
(.01)\end{array}$ & $\begin{array}{c}0.02 \\
(.01)^{*}\end{array}$ & $\begin{array}{c}0.02 \\
(.01)^{*}\end{array}$ \\
\hline GDP per capita & $\begin{array}{l}0.10 \\
(.20)\end{array}$ & $\begin{array}{l}-0.24 \\
(.13)^{*}\end{array}$ & $\begin{array}{c}-0.02 \\
(.16)\end{array}$ \\
\hline $\mathrm{Chi}^{2}$ (p-value) & 0.00 & 0.00 & 0.00 \\
\hline \# of observations & 131 & 131 & 131 \\
\hline R-Squared & 0.31 & 0.36 & 0.39 \\
\hline
\end{tabular}

Notes: Coefficients listed with standard errors in parentheses. * $* *$ and $* * *$ refers to significance at the $1 \%, 5 \%$ and $10 \%$ levels, respectively. First stage results in Appendix. 
Table 12 Impact of Sectoral Aid on Exports

\begin{tabular}{|c|c|c|c|c|}
\hline Method of Estimation & $\begin{array}{l}\text { OLS } \\
(1)\end{array}$ & $\begin{array}{l}\text { OLS } \\
(2)\end{array}$ & $\begin{array}{l}\text { OLS } \\
(3)\end{array}$ & $\begin{array}{l}\text { OLS } \\
(4)\end{array}$ \\
\hline Aid to trade & $\begin{array}{c}0.2 \\
(.02)\end{array}$ & - & - & - \\
\hline Aid to infrastructure & - & $\begin{array}{c}0.10 \\
(.03)^{* * *}\end{array}$ & - & - \\
\hline Aid to agriculture & - & - & $\begin{array}{l}0.01 \\
(.02)\end{array}$ & - \\
\hline Aid to Education & - & - & - & $\begin{array}{l}0.03 \\
(.02)\end{array}$ \\
\hline School Enrollment & $\begin{array}{c}0.01 \\
(.003)^{* * *}\end{array}$ & $\begin{array}{c}0.01 \\
(.003)^{* * *}\end{array}$ & $\begin{array}{c}0.01 \\
(.003)^{* * *}\end{array}$ & $\begin{array}{c}0.01 \\
(.03)^{* * * *}\end{array}$ \\
\hline Exchange rate & $\begin{array}{c}-0.02 \\
(.02)^{* * *}\end{array}$ & $\begin{array}{l}-0.01 \\
(.02)\end{array}$ & $\begin{array}{c}0.0002 \\
(.02)\end{array}$ & $\begin{array}{l}-0.01 \\
(.02)\end{array}$ \\
\hline Economic policy & $\begin{array}{c}0.09 \\
(.05)^{* *}\end{array}$ & $\begin{array}{c}0.11 \\
(.04)^{* *}\end{array}$ & $\begin{array}{c}0.10 \\
(.05)^{* *}\end{array}$ & $\begin{array}{c}0.10 \\
(.04)^{* *}\end{array}$ \\
\hline Institutional quality & $\begin{array}{c}0.25 \\
(.03)^{* * *}\end{array}$ & $\begin{array}{c}0.26 \\
(.03)^{* * *}\end{array}$ & $\begin{array}{c}0.29 \\
(.04)^{* * *}\end{array}$ & $\begin{array}{c}0.27 \\
(.04)^{* * *}\end{array}$ \\
\hline Liberalization Policy & $\begin{array}{l}0.01 \\
(.20)\end{array}$ & $\begin{array}{l}0.01 \\
(.20)\end{array}$ & $\begin{array}{l}0.02 \\
(.20)\end{array}$ & $\begin{array}{l}0.02 \\
(.20)\end{array}$ \\
\hline GDP per capita & $\begin{array}{l}0.07 \\
(.05)\end{array}$ & $\begin{array}{c}0.17 \\
(.06)^{* * *}\end{array}$ & $\begin{array}{l}0.07 \\
(.06)\end{array}$ & $\begin{array}{l}0.08 \\
(.05)\end{array}$ \\
\hline $\begin{array}{c}\mathrm{Chi}^{2} \text { (p-value) } \\
\text { \# of observations } \\
\text { R-Squared }\end{array}$ & $\begin{array}{l}0.00 \\
118 \\
0.60\end{array}$ & $\begin{array}{c}0.00 \\
131 \\
0.53\end{array}$ & $\begin{array}{l}0.00 \\
131 \\
0.69\end{array}$ & $\begin{array}{l}0.00 \\
131 \\
0.69\end{array}$ \\
\hline
\end{tabular}

Notes: Coefficients listed with standard errors in parentheses. *,** and *** refers to significance at the $1 \%, 5 \%$ and $10 \%$ levels, respectively. First stage results in Appendix. 
Table 13 Impact of Sectoral Aid on Exports

\begin{tabular}{|c|c|c|c|c|}
\hline Method of Estimation & $\begin{array}{c}\text { 2SLS } \\
(1)\end{array}$ & $\begin{array}{c}\text { 2SLS } \\
(2)\end{array}$ & $\begin{array}{c}\text { 2SLS } \\
(3)\end{array}$ & $\begin{array}{c}\text { 2SLS } \\
(4)\end{array}$ \\
\hline Aid to trade & $\begin{array}{c}0.15 \\
(.06)^{* *}\end{array}$ & - & - & - \\
\hline Aid to infrastructure & - & $\begin{array}{c}0.22 \\
(.07)^{* * *}\end{array}$ & - & - \\
\hline Aid to agriculture & - & - & $\begin{array}{c}0.17 \\
(.10)^{* *}\end{array}$ & - \\
\hline Aid to Education & - & - & - & $\begin{array}{c}0.16 \\
(.06)^{* *}\end{array}$ \\
\hline School Enrollment & $\begin{array}{c}0.01 \\
(.004)\end{array}$ & $\begin{array}{c}0.02 \\
(.004)\end{array}$ & $\begin{array}{c}-0.001 \\
(.01)^{* *}\end{array}$ & $\begin{array}{c}0.003 \\
(.01)\end{array}$ \\
\hline Exchange rate & $\begin{array}{l}-0.12 \\
(.06)^{*}\end{array}$ & $\begin{array}{r}-0.06 \\
(.06)\end{array}$ & $\begin{array}{r}-0.13 \\
(.10)\end{array}$ & $\begin{array}{l}-0.03 \\
(.08)\end{array}$ \\
\hline Economic policy & $\begin{array}{c}-0.04 \\
(.06)^{* *}\end{array}$ & $\begin{array}{c}-0.08 \\
(.06)^{* *}\end{array}$ & $\begin{array}{c}-0.07 \\
(.09)^{* *}\end{array}$ & $\begin{array}{c}-0.05 \\
(.09)^{* *}\end{array}$ \\
\hline Institutional quality & $\begin{array}{c}0.12 \\
(.06)^{* *}\end{array}$ & $\begin{array}{c}0.17 \\
(.05)^{* * *}\end{array}$ & $\begin{array}{l}0.10 \\
(.07)\end{array}$ & $\begin{array}{c}0.12 \\
(.06)^{* *}\end{array}$ \\
\hline Liberalization Policy & $\begin{array}{l}-0.01 \\
(.02)\end{array}$ & $\begin{array}{c}0.004 \\
(.01)\end{array}$ & $\begin{array}{l}0.01 \\
(.02)\end{array}$ & $\begin{array}{l}0.02 \\
(.02)\end{array}$ \\
\hline GDP per capita & $\begin{array}{c}-0.38 \\
(.14)^{* * *}\end{array}$ & $\begin{array}{r}-0.20 \\
(.15)\end{array}$ & $\begin{array}{c}-0.41 \\
(.15)^{* * * *}\end{array}$ & $\begin{array}{l}-0.04 \\
(.21)\end{array}$ \\
\hline $\begin{array}{c}\mathrm{Chi}^{2} \text { (p-value) } \\
\text { \# of observations } \\
\text { R-Squared }\end{array}$ & $\begin{array}{l}0.00 \\
118 \\
0.16\end{array}$ & $\begin{array}{c}0.00 \\
131 \\
0.43\end{array}$ & $\begin{array}{l}0.00 \\
131 \\
0.01\end{array}$ & $\begin{array}{l}0.00 \\
131 \\
0.02\end{array}$ \\
\hline
\end{tabular}

Notes: Coefficients listed with standard errors in parentheses. **** and *** refers to significance at the $1 \%, 5 \%$ and $10 \%$ levels, respectively. First stage results in Appendix. 


\subsection{Conclusion}

In this paper we investigated some questions raised during the course of this study. They are what component of aid is useful in promoting trade in developing countries? We found that aid to sectors was useful in promoting trade, with aid to trade policy, infrastructure, agriculture and education being significant in promoting trade. This is consistent with past findings by Morrissey et al (2004) and Velde and Cali (2009) who state that channeling aid to productive sectors in an economy could boost export oriented growth. Aid to industry had no impact on trade so we neglected it in our results. It was likely that finished goods from developing countries do not compete favorably with goods from developed countries and technology is often a problem in developing countries making it difficult to produce. Effective aid had contributed less to exports compared to official aid. However multilateral aid proved more useful promoting export than bilateral aid this is attributable to conditions associated with multilateral aid disbursements which make them more effective in promoting exporting.

We also investigated if economic policies and institutional quality improves or decreases aid effectiveness in promoting trade in Africa? We found that economic policy and the quality of institutions in Africa generally weakens the effectiveness of aid in promoting trade. The interactive variables "aid*government economic policy" "aid*institutional quality" and "aid*natural resources" had a reduced effect on trade. This is consistent with past findings such as Burnside and Dollar (2002) and (2004) which state that aid will be effective in the presence of good policies and other findings by Sachs and Warner (1995) and Ross (2001) that suggest the presence of natural resources and weak institutions can affect economic development in developing countries. The inclusion of natural resources in our model caused our model to suffer from misspecification resulting in negative R-squared so we exclude it and used its interaction with aid in our subsequent GLS regression. This interactive variable aid* natural resources exerted a reduced effect on trade across all sectors, reducing aid effectiveness across sectors. Therefore diversifying the economy in many African countries should therefore be a strong concern to governments.

The policy implications of our findings is that economic policy has a significant effect on aid effectiveness in Africa, therefore donors should continue to emphasize the need for African countries to float sound and consistent economic policies. Such policies could be vital in shoring up investor's confidence and ensure the effective use of aid to boost capacities that can improve trade and stimulate export oriented growth on the long run. Secondly channeling aid to sectors that are likely to improve export capacities in developing countries could likely improve the way that aid can be used to drive growth in an effective manner. Aid given to trade capacities 
will likely fulfill the short term intention of giving aid to developing countries since it is likely to contribute to export driven growth in many African countries allowing for a discontinuation of aid giving policies to promote growth. Over reliance on natural resources continue to remain an impediment to the growth of other sectors in many African economies, promoting diversification is likely to help prevent shocks (due to price fluctuation in natural resources) in many African countries that rely on specific natural resources for income. The reliance on these natural resources as a source of alternative revenue often prevents governments from implementing sound policies that could improve growth. Alternative revenue sources through for example a creation of effective taxation scheme can help create other sources of financing government activities thereby reducing overdependence on resource derived revenues.

\section{References:}

Baltagi, B.H., 2005.Econometric Analysis of Panel Data. $3^{\text {rd }}$ edition. New York: John Wiley and Sons.

Baltagi, B.H., and Wu, P.X., 1999. "Unequally Spaced Panel Data Regressions with AR(1) Disturbances." Econometric Theory, 15:814-823.

Boone, P., 1994. The impact of foreign aid on savings and growth. Mimeo, London School of Economics.

Boone, P., 1996. "Politics and the effectiveness of foreign aid."European Economic Review, 40:289-329.

Bourguignon F. and Sundberg M., 2008 "Aid Effectiveness - Opening the Black Box”.American Economic Review, 97(2) pp. 316 - 321

Burnside C. and Dollar D., 2000.“Aid, Policies and Growth".American Economic Review, 90 (4), pp. 847 - 868.

Cali, M. and D. W. Velde., 2011. "Does Aid For Trade Really Improve Trade Performance?",World Development, 39(5):725-740.

Central Intelligence Agency., 2011. CIA World Factbook, 2011.Accessed online February 11, 2012 at http://cia.gov/library/publications/the-worldfactbook.

Chang, C. C.; Fernandez-Arias, E., and Serven, L., 1999.Measuring Aid Flows: A New Approach. Washington: World Bank, Development Economics Research Group.

Clemens, M.A.; C.J. Kenny \& T.J. Moss., 2004. The trouble with the MDGs: confronting expectations of aid and developments success. Working Papers no. 40. Center for Global Development.

De Long, B. and B.Eichengreen.,1991. The Marshall Plan: History of the Most Successful Structural Adjustment Program, NBER Working Paper 3899. 
De Renzio, Paolo., 2006. Aids, Budgets and Accountability: A Survey Article Development Policy Review, 24(6): 627-645.

Douclouliagos H. and Paldam M., 2007 "A meta-analysis of development aid allocation: The effects ofIncome level and population size" University of Arhus Denmark Working Paper.

Djankov et al., 2006. "Does Foreign Aid Help?" Cato Journal, 26 (1): 1-28. Easterly W., 2003. “Can Foreign Aid Buy Growth?” Journal of Economic Perspective 17 (3) pp. $23-48$

EconomyWatch., 2010. Africa Economy, accessed online February 28, 2012 at http://www.economywatch.com/world_economy/africal

Gormanee, K., Morrissey, O., Mosley, P. and A.Verschoor. 2003. "Aid,ProPoor Government Spending, and Welfare."CREDIT Research Paper.No 03/03.

Jempa, C.1991. The Tying of Aid, OECD Development Center, Paris Jensen, T.M. 2008. How Does Aid Work? A Literature Review of Aid Effectiveness and Welfare Studies.DIIS Working Paper, 2008/29.

Johnson, H. G., 1967. Economic Policies toward Less Developed Countries.Washington: Brookings Institution.

Karingi, S.N. and V. Leyaro. 2009. Monitoring Aid for Trade in Africa: An Assessment of the Effectiveness of the Aid for Trade. African Trade Policy Centre, Working Paper No.83.

Knack S., 2001. "Aid Dependence And The Quality of Governance: Cross Country Empirical Test". Southern Economic Journal

McPherson, M.F. and T. Rakovski. 2001. "Understanding the Growth Process in Sub-Saharan Africa: Some Empirical Estimates," African Economic Policy Discussion Paper.

Morrissey O., Osei R., McGillvray M., Lloyd T., 1992. "Investigating the Relationship between Aid and Trade Flows". A CREDIT (Centre for Research in Economic Development and International Trade) Research Paper, 38 (10), pp

Morrissey O., Osei R., Lloyd T., 2004. "The Nature of Aid and Trade Relationships". European Journal of Economic Research, 16 (2), pp. 354 374.

Mosley P., Hudson J., Vershoor A., 2004. "Aid Poverty Reduction and The New Conditionality". The Economic Journal, 114(496), pp. 217- 243.

Osborne E., 2002. "Rethinking Foreign aid" Cato Journal. 22(2): 297-316.

Pettersson J., 2004. "Foreign Sectoral Aid Fungibility, Growth, and Poverty Reduction".Journal of Economic Literature, 68(2), pp. 310- 329

Svensson J., 2000. "When Is Foreign Aid Policy Credible? Dependence and Conditionality" Journal of Development Economics, 61(2000), pp. 61- 84.

Thirlwall, A. P. 1976. "When Is Trade More Valuable than Aid?" Journal of Development Studies 13: 35-41. 
United Nations, 2010.MDG Gap Task Force Report: The Global Partnership for Development at a Critical Juncture, United Nations: New York.

Wooldridge, J.M. 2010.Econometric Analysis of Cross Section and Panel Data, MIT Press: Cambridge, MA.

World Bank. 2012. World Development Indicators. Accessed online February 11, 2012 at http://data.worldbank.org.

Yeats, A. 1982. "Development Assistance: Trade vs. Aid and the Relative Performance of Industrial Countries." World Development 10: 863-69.

Appendix A. Table 14 Trade Regressions With Aid*Economic Policy Interaction

\begin{tabular}{|c|c|c|c|c|}
\hline Method of Estimation & $\begin{array}{l}\text { GLS } \\
\text { (1) }\end{array}$ & $\begin{array}{l}\text { GLS } \\
\text { (2) }\end{array}$ & $\begin{array}{l}\text { GLS } \\
\text { (3) }\end{array}$ & $\begin{array}{l}\text { GLS } \\
\text { (4) }\end{array}$ \\
\hline Aid to trade & $\begin{array}{c}0.19 \\
(.07)^{* * *}\end{array}$ & - & - & - \\
\hline Aid to Trade*Policy & $\begin{array}{c}0.01 \\
(.01)^{* *}\end{array}$ & - & - & - \\
\hline & & - & - & - \\
\hline Aid to infrastructure & - & $\begin{array}{c}0.16 \\
(.19)^{* * *}\end{array}$ & & \\
\hline Aid to Infrastruc.*policy & - & $\begin{array}{c}0.01 \\
(0.01)^{* *}\end{array}$ & - & - \\
\hline Aid to agriculture & - & - & $\begin{array}{c}0.37 \\
(.13)^{* * *}\end{array}$ & - \\
\hline Aid to Agriculture*policy & - & - & $\begin{array}{c}0.02 \\
(.01)^{* *}\end{array}$ & - \\
\hline Aid to Education & - & - & - & $\begin{array}{c}0.64 \\
(.22)^{* * *}\end{array}$ \\
\hline Aid to Education*policy & - & - & - & $\begin{array}{c}0.01 \\
(.01)^{* *}\end{array}$ \\
\hline Aid to industry & - & - & - & - \\
\hline Aid to Industry*policy & - & - & - & - \\
\hline School Enrollment & $\begin{array}{c}0.01 \\
(.003)^{* * *}\end{array}$ & $\begin{array}{c}0.01 \\
(.003)^{* * *}\end{array}$ & $\begin{array}{c}0.01 \\
(.003)^{* * *}\end{array}$ & $\begin{array}{c}0.01 \\
(.003)^{* * *}\end{array}$ \\
\hline Exchange rate & $\begin{array}{c}0.07 \\
(.02)^{* * *}\end{array}$ & $\begin{array}{l}0.02 \\
(.02)\end{array}$ & $\begin{array}{c}0.22 \\
(0.14)\end{array}$ & $\begin{array}{c}0.01 \\
(0.02)\end{array}$ \\
\hline Institutional quality & $\begin{array}{c}0.27 \\
(.04)^{* * *}\end{array}$ & $\begin{array}{c}0.26 \\
(.04)^{* * *}\end{array}$ & $\begin{array}{c}0.26 \\
(.04)^{* * *}\end{array}$ & $\begin{array}{c}0.26 \\
(.04)^{* * *}\end{array}$ \\
\hline Liberalization rate & $\begin{array}{c}-0.03 \\
(.03)^{* * *}\end{array}$ & $\begin{array}{c}-0.03 \\
(.03)^{* * *}\end{array}$ & $\begin{array}{c}-0.03 \\
(.03)^{* * *}\end{array}$ & $\begin{array}{c}-0.03 \\
(.03)^{* * *}\end{array}$ \\
\hline GDP per capita & $\begin{array}{l}0.07 \\
(.05)\end{array}$ & $\begin{array}{c}0.08 \\
(.05)^{* *}\end{array}$ & $\begin{array}{l}0.07 \\
(.05)\end{array}$ & $\begin{array}{l}0.08 \\
(.05)\end{array}$ \\
\hline $\mathrm{Chi}^{2}$ (p-value) & 0.00 & 0.00 & 0.00 & 0.00 \\
\hline \# of observations & 131 & 131 & 131 & 131 \\
\hline R-Squared & 0.62 & 0.62 & 0.62 & 0.62 \\
\hline
\end{tabular}

Notes: Coefficients listed with standard errors in parentheses. *, ** and *** refers to significance at the $1 \%, 5 \%$ and $10 \%$ levels, respectively. First stage results in Appendix. 
Appendix B. Table 15 Trade Regressions With Aid*Institutions Interaction

$\begin{array}{lllll}\text { Method of Estimation } & \text { GLS } & \text { GLS } & \text { GLS } & \text { GLS }\end{array}$

(1)

(2)

(3)

(4)

Aid to trade

Aid to Trade*Institutions

Aid to infrastructure

Aid to Infrastr.*Institutions

Aid to agriculture

Aid to Agric*Institutions

Aid to Education

Aid to Educ*Institutions

Aid to industry

Aid to Industry*Institutions

School Enrollment

$$
\begin{gathered}
0.01 \\
(.003)^{* * *}
\end{gathered}
$$

Exchange rate

Liberalization rate

GDP per capita

$\mathrm{Chi}^{2}$ (p-value)

\# of observations

R-Squared

$$
0.02
$$

$$
-0.05
$$$$
(.03)^{* * * *}
$$

$$
0.07
$$

0.00

131

0.62
0.22

$(.07) * * *$

$-0.04$

$(.01)^{* * * *}$

$\begin{array}{cc}- & 0.84 \\ - & (.28)^{* * *} \\ -0.06 \\ & (0.01)^{* * *}\end{array}$

0.67

$(.22)^{* * * *}$

$-0.04$

$(.01)^{* *}$

(13)**

$-0.04$

$(.01)^{* * *}$

$$
-
$$$$
(.01)^{* *}
$$$$
-
$$

$$
\begin{gathered}
0.01 \\
(.003)^{* * *} \\
0.02 \\
(.02)
\end{gathered}
$$

$-0.04$

$(.03)^{* * * *}$

$$
0.08
$$$$
(.05)^{* * *}
$$

0.00

131

0.62

$$
\begin{gathered}
0.01 \\
(.003)^{* * * *} \\
0.02
\end{gathered}
$$

$-0.04$

$(.03)^{* * * *}$

0.07

(.05)

0.00

131

0.62
0.01 $(.003)^{* * *}$

0.02

$-0.04$ $(.03)^{* * * *}$

0.08

0.00

131 0.62

Notes: Coefficients listed with standard errors in parentheses. *, ** and *** refers to significance at the $1 \%, 5 \%$ and $10 \%$ levels, respectively. First stage results in Appendix. 


\section{Appendix C. Table 16 Trade Regressions With Aid*Natural Resources} Interaction

Method of Estimation

Aid to trade

Aid to Trade*Resource

Aid to infrastructure

Aid to Infrastr.* Resource

Aid to agriculture

Aid to Agric.* Resource

Aid to Education

Aid to Educ.* Resource

Aid to industry

Aid to Industry* Resource

School Enrollment

Exchange rate

Institutional quality

Liberalization rate

GDP per capita

$\mathrm{Chi}^{2}$ (p-value)

\# of observations

R-Squared

\section{GLS}

(1)

0.22

$(.10)^{* * * *}$

0.0004

(.0004)
GLS

(2)


$\begin{array}{cc}- & 0.89 \\ - & (.40)^{* * *} \\ - & 0.0001 \\ & (.001)\end{array}$

-

0.42

$(.19)^{* * * *}$

0.0004

(.0005)

0.71

$(.32)^{* * *}$

0.0004

$(.0005)^{* *}$

$\begin{array}{cccc}- & - & - & - \\ 0.01 & 0.01 & 0.01 & 0.01 \\ (.004)^{* *} & (.004)^{* *} & (.004)^{* *} & (.004)^{* *}\end{array}$

0.04
$(.03)^{* * *}$

0.04

0.04

0.04

(.03)

(0.03)

(0.03)

$$
\begin{gathered}
0.19 \\
(.04)^{* * *}
\end{gathered}
$$

0.19

$(.05)^{* * *}$

0.19
$(.05)^{* * *}$

0.19

$(.05)^{* * * *}$

$$
\begin{gathered}
-0.04 \\
(.03)^{* * *}
\end{gathered}
$$

$-0.04$

$(.03) * * *$

-0.04
$(.03) * * *$

$-0.04$

$(.03)^{* * * *}$

0.07

0.08

(.07)

0.07

(.07)

0.07

(.07)

0.00

0.00

0.00

0.00

131

131

131

131

0.61

0.61

0.61

0.61

Notes: Coefficients listed with standard errors in parentheses. *,** and *** refers to significance at the $1 \%, 5 \%$ and $10 \%$ levels, respectively. First stage results in Appendix. 